\title{
Abstracts
}

\author{
Karin Hansen \\ The Institutional Perspective in Political Science
}

During the 1980es a new institutionalism or institutional perspective has been called for in political science. Across quite different - marxist as well as non-marxist - theoretical schools and positions, it has been argued that political life is an organized life, and that the institutional and organizational forms of politics smake a difference $\propto$. The institutional forms and structures play an autonomous and important role. The understandings of the kind of role the political institutions play differ. But there is an over all agreement about their importance and about the need to bring political institutions back into the forefront of political analysis, in order to increase our knowledge and understanding of the role they play and the difference they make to political life.

\section{Peter Nedergaard Public Choice and European Integration in the 1980 s}

Traditional integration theories can hardly catch the lability of European integration in the 1980s. The reason for that being, partly, that the political and economic system has not been put on the same formula of integration. Partly, that the analytical starting point has not been the actors of the political system. Therefore, one primary foundation of analysis of European integration should be the demand of political decisions by actors and coalitions of actors in the political system. Another primary foundation of analysis of European integration should be the welfare effects of the shifting demand of political decisions. When analysing European integration in the 1980 s with these wtheoretical glasses $\alpha$ it is possible to point out the formation of a new strong coalition of actors on the demand side of the political market as an important explanation of the accelerated European integration in the 1980s.

\section{René Bugge Bertramsen A Society-led Growth: The Danish Growth Model of the 1990s?}

By developing the concept of a civil society strategy and incorporating this concept into the framework of Jessop's state analysis, it is argued that the alternative to either a state-led or marked-led growthmodel is a society-led growth. With its highly developed welfare state and well organized and powerful professional and interest organizations, Denmark is a paradigmatic case of a societyled growth. This implies, in turn, that the legacy of the welfare state and powerfull organisations might turn out to facilitate rather than obstruct growth in the 1990s. By further elaborating the concept of society-led growth it might be possible to overcome the dichotomy between a state- and market-led growth and show that politics matters to economic development beyond wage-negatioations and state subsidies. 